\title{
A Comparative Study of Tibetan and English Taboo Culture
}

\author{
Chun Dai*
}

\author{
(Sichuan Minzu College, Sichuan, China, 626001) \\ Khams Research Institute of Translation on Minority Cultures \\ *Corresponding author. Email:27275600@qq.com
}

\begin{abstract}
Today, with the globalization of culture, the Tibetan people have more and more social contacts with the British and American people, especially in the cross-cultural communication, they often encounter a very sensitive issue, which is taboo. This paper introduces the language taboos, dietary taboos and religious taboos in Tibetan and English taboo culture in order to arouse people's attention, It will help the Tibetan and British people to communicate smoothly and deepen their understanding of Tibetan customs and culture, social and cultural characteristics and national characteristics, so as to realize the mutual promotion and mutual learning of Tibetan and British cross-cultural communication.
\end{abstract}

Keywords: Tibetan and English, Taboo culture, Comparison.

\section{INTRODUCTION}

Today, with the globalization of culture, the Tibetan people have more and more social contacts with the British and American people, especially in the crosscultural communication, they often encounter a very sensitive issue, which is taboo. Taboo, some writing "Tabu or Tapu", Equivalent to taboos, abstain from, precepts, etc). Taboo is derived from the Tonga language of the Pacific Tonga, 18th century English navigator James. Cook first discovered the taboo custom among Tonga residents and introduced the word into the English language. As its name implies, the so-called taboo is in the daily life or work of people to some of the self-restraint. Taboo culture is a kind of culture between spiritual culture and behavior culture, and does not belong to any of them. In fact, taboo is a cultural phenomenon common to all nationalities in the world, but the content and form of taboo are different. Taboos are like an invisible discipline that constrains people's language and behavior and keeps them from crossing the line in the Forbidden Zone. Taboo culture is almost ubiquitous, in the same culture due to regional or subcultural differences, taboos have similarities and differences. In different regions with different cultures, especially in cross-cultural communication such as Tibetan people and British and American people, the differences of taboo culture are even greater, Thus, it has set up a lot of obstacles for each other's cross- cultural communication, so that people have to pay attention to it, have to avoid it, in order to carry out the communication smoothly.

\section{CULTURAL CONTRAST BETWEEN TIBETAN AND ENGLISH TABOOS}

It's not hard to see taboos everywhere, from clothing, food, housing, transportation, social interaction, to politics, diplomacy, culture and other activities. Therefore, the article introduces the language taboos, dietary taboos and religious taboos in the Tibetan-English Taboo culture in order to arouse people's attention. So as to deepen the understanding of Tibetan custom and culture, social and cultural characteristics and national characteristics of the people of all ethnic groups in the world, and to realize the mutual promotion and mutual learning of Tibetan and English culture, to enable the Tibetan- English people to communicate smoothly.

\subsection{Comparison of Language Taboos in Tibetan and English}

Language taboo is a kind of consciousness produced by people's worship of language spirit. On the one hand, it shows the worship of language spirit, on the other hand, it shows the prohibition or substitution of some 
languages in special occasions. In this way, language is endowed with a superhuman feeling and superhuman power which it does not possess. People think that language is the source of misfortune and blessing. If anyone offends this source, he will get double punishment; On the contrary, he who fawns upon this source is protected and blessed [1]. The Tibetan-English taboo language is reflected in all aspects of social life, religion and religious belief is an important field of the existence of taboo language. Tibetans believe that language has amazing power. Generally speaking, the word "death" is taboo. If we hear someone say "So-andso will die a horrible death", it's full of curse. As a result of the language taboo, the taboo of "death" comes into being, such as "parinirvana" and "nirvana" for the living buddhas and eminent monks, "end of life" and "natural death" for the long-lived elderly. Another example: Tibetans rarely speak the names of the dead. They always use the word "Xing Xia" (meaning to go to a pure land, often used by senior monk Dade and other respected people), the euphemism "Ce Dai" (meaning to die, but used by ordinary people) was used instead as a sign of respect. For the deceased elders, they always use the name "Palai" as the father of heaven and "Malai"as the mother of heaven. In daily life, encountered some important things, often like swearing. Such as: "Nimalasa" (the testimony of Sun Yat Sen), "Genqusong" (the testimony of Sanbao), "Jueyishinobu" (the testimony of Ruyi treasure Sakyamuni Buddha), etc. Such oaths and curses are the result of worship of language. There are also early morning out, weddings, festivals and other festive occasions, avoid saying some unlucky words, in order to avoid disaster. On the morning of the New Year's Day, it is forbidden to say "No, not enough, sickness" and other unlucky words. It is taboo to say "kill, slaughter or chop" on Gautama Buddha or religious festivals. In temples, holy mountains, holy places and other places, "bad language" and "profanity" are taboo.

British and American culture is deeply influenced by Christianity. Even those who do not believe in ghosts and gods will not offend God with disrespectful language. Therefore, religious belief is a very important field of taboos [2]. In Christianity, the name of the Western God (Jehovah) is the biggest taboo, under no circumstances can one say or misuse the name of God. According to the records of Exodus in the Old Testament, there are "ten commandments" that the Israelites must obey, The Third Commandment is "That shalt not speak my name in vain". When talking about taboos in his book language, American linguist Leonard Bloomfield said: English religious words such as God, Devil, Heaven, Hell, Christ, Jesus, and damn etc, can only be used properly in serious conversation, if you break this rule, people will blame you or avoid you. Racial Discrimination is an important part of language taboos in British and American cultures, especially in
American English. Historically, Black Americans have been discriminated against by the White supremacy, who have used vicious racial discrimination words to curse black people. These discriminative words have become more sensitive, with some words turning into outright taboos and others into semi taboos. For example, the words "Nigger, Niggra, Niggruh" and so on are all completely taboo in terms of strong insults. "Niggra or Niggruh" is a more insulting form of spelling that is based on Southern American pronunciation. Today, Blacks are known as Blacks or Colored people. Racial Discrimination in American English is not limited to African Americans, such as Dagos for Italian Americans, Kikes for Jewish Americans, Polacks for Poles for Americans, and Chinks for Chinese American, in fact, it is also a kind of taboo or semi-taboo language, which should attract the attention of English speakers. The existence of these taboos promotes the development of language and enriches language vocabulary, People taboo someone, something, will be involved in it, to be involved, then we have to be scrupulous. Therefore, in cross-cultural, cross-ethnic, cross-regional communication, we should pay attention to the use of taboo words, so as to avoid unnecessary conflicts.

\subsection{Comparison of Dietary Taboos between Tibetan and English}

Diet is an important part of a person's life. As the saying goes, "food is the most important thing for the people", it can be seen that in the long life process, every country and nation has formed its own unique diet culture, and dietary taboos are an important part of dietary culture. This kind of dietary taboo includes not only the content of diet, that is, what kind of food to avoid, but also the way of diet, that is, a certain behavior or way to avoid when eating

In the Tibetan diet taboo, when the Tibetan hands the knife to the guest, knife point can't toward guest, the handle must be toward guests: when the guests leave, they should avoid having tea left in their bowls; they must also finish their meals, which is related to the traditional Tibetan virtues of diligence and frugality. In the meat-eating aspect, the Tibetan taboo is also many. They usually only eat beef and mutton instead of horse, donkey, mule and dog. Some Tibetans do not even eat chicken, pork or eggs. There are fish, shrimp, snakes, eels and seafood, except for some urban residents (mostly young people) eat a small amount of food, and the vast majority of pastoral and agricultural areas of the people never eat. Even if Tibetans eat beef and mutton, they cannot eat fresh meat slaughtered that day. They must wait a day before eating it. The meat slaughtered that day is called "Ningxia" (meaning "meat killed during the day"), It is believed that although the animal has been butchered, its soul remains and does not leave its body until a day later. They never prey on birds, 
pheasants, especially snowy pheasants like "La chargome" (lha-bya-gong-mo), Tibetans respect birds as gods, taboo hunting. In the meat taboo, they also taboo to eat fish. In Eastern Tibet, people rarely eat fish, believing that they are the pets of the Dragon Gods and their fish bodhisattvas, and that if they are harmed or touched, they will catch diseases. The formation of their meat-eating taboo is the result of the influence and domination of the religious concept of non-killing of animals. Among dietary taboos, Tibetans also have more taboos against eating garlic. As a condiment, garlic is usually eaten by people, but if you want to go to the Holy Place, you must not eat garlic. The stink after eating garlic is taboo and dirty the holy place. They believe it is not advisable to visit temples or other holy places for seven days after eating garlic, as it takes time to remove the stench [3]. Tibetans like to drink wine, friends and relatives together is no less wine, so in the toast to guests, must use the right hand toast, do not use the left hand, only for the deceased pour wine only with the left hand.

Tibetans have a sacred reverence for the kitchen God, think there is a kitchen god in the Fire Pool, they should be careful to serve him, they must not desecrate or offend the kitchen God, otherwise it will bring disaster. It is forbidden to cross the fire stove, taboo to spit in the fire stove, taboo in the fire pool burning bones, fur and other things. Fire Pond to keep clean, cannot put unclean things on the stove, cannot put his feet on the stove, clean garbage not into the stove burning, also taboo directly on the stove roast meat. Taboo backhand with a spoon to add tea to pour water, which is to add water to the dead act. When pedestrians go out, they need to pray to the Kitchen God for protection. A fire stove made of three stones in the field also needs to be cleaned up when leaving. A small amount of tea or food is placed on each hearth stone as a sacrifice to the kitchen god.

The dietary habits of the Americans are quite different from those of the Tibetans. The dietary taboos in Britain and the United States are shown in their avoidance of fat meat, sticky bones and skin of chickens and ducks (except for the skin of roast ducks and roast chickens). It is forbidden to eat food made from the heads, feet and internal organs of various animals, taboo to eat a variety of special animal meat, such as dog meat, snake meat and so on. Avoid eating garlic, fermented bean curd, shrimp paste, fish sauce and other flavor too strong condiments. They also have many taboos regarding dietary rules. For example, when drinking soup do not make a sound; it is forbidden to gobble while eating; don't clink when using knife and fork to take food; especially not knife and fork clink water cup that will bring bad luck. Take less or none of the food you don't like. When eating a buffet, avoid leaving food on your plate; After dinner, the knife and fork should be put away according to the rules; Don't pick your teeth in public after meals; don't spill salt; Don't talk when your mouth is full of food. When westerners eat, knife and fork cannot point at the guests, you can't put a knife and fork in your mouth and lick the food on it, never put your own cutlery on someone else's table. Americans don't like steamed or braised dishes, they are not allowed to make a sound while eating, not allowed to smoke, not allowed to take food for others, not allowed to ask others to drink, not allowed to discuss disgusting things, not allowed to undress in public, and so on. There are also westerners in drinking there are some taboos, the west of a wide range of alcohol, pay attention to what occasion to drink what wine, what food to drink what wine. For example: aperitif before dinner, dinner with wine, after dinner to drink cocktails or whiskey, the banquet is to drink champagne.

\subsection{Comparison of Religious Taboos between Tibetan and English}

Religious taboo refers to a kind of religious behavior in which people believe in and worship mysterious forces and sacred objects. It is a taboo which is strictly observed and spread among the people by the believers with religious rules, doctrines, sectarian system, gods, and clergy as its content.

It is well known that the Tibetan people are basically a religious people, they mainly believe in Tibetan Buddhism, so taboo culture is mostly related to their religious activities and beliefs. For example: The road to meet the temple, engraved with scripture heap, pagodas and other religious facilities, must dismount from the left to the right around; It is not allowed to cross religious utensils, braziers, and rotating drums, and the wheel of the Sutra is not allowed to rotate in the opposite direction; When sleeping, the feet should not face the shrine Buddha; Take off your hat and sunglasses when you enter the temple; They are not allowed to bring weapons such as knives and guns into the temple, they are not allowed to shout loudly in the temple, and they are not allowed to point fingers in the temple. It is taboo to touch all kinds of religious objects, such as Buddhist statues, sutras, dharma instruments, etc. in the temple, to worship the Buddha, keep your fingers together and your palms up to show respect, to the temple worship can only go in the morning, not in the afternoon. After kowtowing to the living Buddha and eminent monks, Tibetan Buddhists will bow to the living Buddha and let them touch their heads to bless them. This is because the believers believe that the hands of living Buddha have great blessing power, touching the top of the head can exorcise evil spirits and diseases, eliminate disasters and take refuge, turn evil into good, and everything goes well. Tibetans believe that everything in the natural world has its own god. These spirits are omnipresent and can give people good 
or bad luck. They should offer sacrifices to them and never offend them [4]. Tibetans also believe that all the stars in the sky are gods, so avoid pointing to the number of stars. Black cloth or silk thread should not be used in divination, because black is often associated with evil spirits such as the devil or other evil ghosts, which will lead to the bad luck of divination ceremony.

People in Britain and America mainly believe in Christianity (Christianity is a general term for the sects that believe in Jesus as their savior, as well as various sects such as Catholicism, Protestantism and the Orthodox Eastern Church).The core of Christian religious taboos is embodied in "The Ten Commandments" in the Bible, which are:
A. "You shall have no other gods before me".
B. "Do not worship idols".
C. "That shalt not speak my name in vain".
D. "Remember the Sabbath day".
E. "Honor your father and your mother".
F. "You shall not murder".
G. "You shall not commit adultery".
H. "You shall not steal".
I. "You shall not bear false witness against your neighbor".
J. "You shall not covet your neighbor's house".

There are other taboos in Christianity besides the "Ten Commandments of God". For example, people remember the story of Jesus being betrayed and crucified by a traitor. In his memory, the church designated Good Friday as "Good Friday", The nearest Friday before Easter every year is considered an unlucky day in the west, when one cannot do the carpentry work of nailing nails, etc.

The Catholic Taboo, in addition to the "Ten Commandments of God", it also has its own unique some taboos. For example: attending a funeral taboo to wear colorful clothing; In the funeral process, do not laugh loudly; two or three weeks after the funeral, relatives of the deceased to see guests, within a year to avoid large banquet or dance. Besides, Catholics aren't allowed to get married; Catholics in Italy are forbidden to use Christmas trees for Christmas; Yugoslav Catholics do not marry on Tuesdays and Fridays. Protestantism is the name given to the various Protestant sects in the Protestant Reformation that have seceded from Catholicism and are found in English speaking countries, there are 12 kinds of religious taboos, including the contents of "God's Ten Commandments", but also new regulations, which reflect the new ideal of Protestant Reformation Protestants.
A. "Prohibition of the making and worship of all idols".
B. "It is forbidden to worship all natural things such as animals, plants, celestial bodies (stars,

Sun, Moon)".

C. "It is forbidden to associate with people who are idolatrous or nature worshippers, let alone to marry them".

D. "Prohibition of worship of gods of other religions".

E. "Do not be indifferent to God in your daily life. It is blasphemy not to pray to God before meals and before going to bed".

F. "Love all men, forgive the enemy, and there can be no malicious retaliation against anyone".

G. "Not jealous, not pride, don't do shy things, never pursue selfish interests, not easily angry".

H. "Living a simple life, no extravagance and waste, no smoking, no drinking, not be lured by material desire and carnal desire, abide by the rules".

I. "Believers should not marry non-believers".

J. "Polygamy or polyandry is strictly prohibited".

K. "A wife should not leave her husband".

L. "You shall not bear false witness against your neighbor".

\section{CONCLUSION}

In the context of the development of cultural globalization, the taboo cultures of various regions and nations show a tendency of mutual influence and integration, Taboo culture is no longer negative, superstitious and ignorant in the traditional sense, In the cross-cultural communication, it increasingly shows its positive, reasonable and scientific role as a social norm. As the saying goes, "when entering the country, ask for Prohibition, when entering the country, ask for taboo, when entering the country, and ask for custom". Learning about the Tibetan-English Taboo culture and its differences can enhance mutual understanding and identification in communication, It can avoid the communication failure caused by "Taboo", and finally achieve the goal of Tibetan-English cross-cultural communication.

\section{ACKNOWLEDGMENTS}

This research is financially supported by Sichuan Minzu College Project "A comparative study of Tibetan and English taboo culture" (No:XYZB19011SB). And "A comparative study of Tibetan, English and auspicious culture from the perspective of cultural anthropology" (No: XYZB18006SA ).

\section{REFERENCES}

[1] $\mathrm{Hu}$ Wenzhong. Comparison of Chinese and English cultural customs [M]. Foreign Language Teaching and Research Press.2010. P234-236. 
[2] Jiang Ya-yuan. Similarities and differences between Chinese and English taboo words and their changes [J]. Overseas English.2013.10. P272276.

[3] Kwan Pei and Joab, author. Translation to Xiang
Hong-jia. Tibetan folklore. See Collection of translated works of Foreign Tibetology Studies(9)1986. P273-278

[4] Ling Li .The Tibetan folk culture of Kangba [M]. People's Publishing House.2012.p209-315. 